\title{
A mesophotic record of the gall crab Opecarcinus hypostegus from a Curaçaoan reef
}

\section{Sancia ET van der Meij ${ }^{*}$, Kaj M van Tienderen, Bert W Hoeksema}

Department of Marine Zoology, Naturalis Biodiversity Center, Darwinweg 2, 2333 CR Leiden, The Netherlands.

* Corresponding author email: <Sancia.vanderMeij@naturalis.nl>.

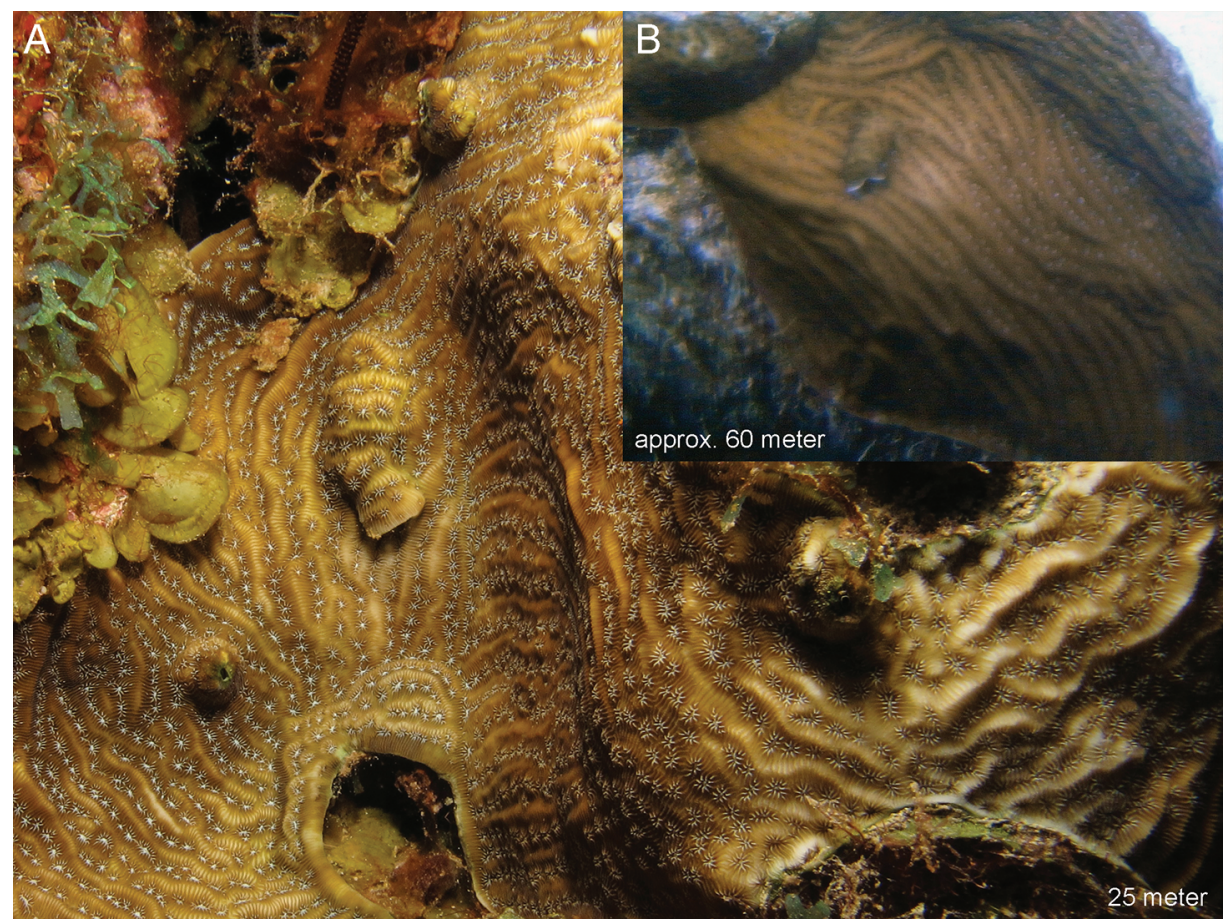

Curaçao, Dutch Caribbean, is home to three species of gall crabs belonging to Cryptochiridae, a family obligatorily associated with a wide range of scleractinian host species. Gall crabs are reliant on their host coral; females are sedentary and never leave their dwelling (van der Meij 2014a). One of the three Atlantic gall crab species is Opecarcinus hypostegus (Shaw and Hopkins, 1977), which inhabits corals of the genus Agaricia. Corals of this genus are abundant in the photic zone $(<30 \mathrm{~m})$, but also in the mesophotic zone $(30-150 \mathrm{~m})$, where they predominantly belong to Agaricia grahamae Wells, 1973 and Agaricia lamarcki MilneEdwards and Haime, 1851. The latter was found to be most abundant at depths of 25-60 m (Bongaerts et al. 2013).

Kropp and Manning (1987) provide occurrence data for O. hypostegus from 1 to $27 \mathrm{~m}$ depth, based on museum specimens collected at various Atlantic localities. Data from off Curaçao showed that $O$. hypostegus occurrences range from shallow (approximately $1-5 \mathrm{~m}$ ) down to $35 \mathrm{~m}$ depth over all Agaricia hosts (van der Meij 2014a). Belt transect surveys at 6, 12, and 18 $\mathrm{m}$ depth revealed that $O$. hypostegus is most abundant at $18 \mathrm{~m}$, where it occurs predominantly in A. lamarcki (van Tienderen and van der Meij unpubl data).

During a survey on 31 March, 2014, with the manned CuraSub submersible launched from Substation Curaçao $\left(12^{\circ} 05^{\prime} 04.14^{\prime \prime} \mathrm{N}, 68^{\circ} 53^{\prime} 53.16^{\prime \prime} \mathrm{W}\right)$, a colony of $A$. lamarcki was observed 
at approximately $60 \mathrm{~m}$ depth (Panel B) exhibiting the characteristic tunnel formed by O. hypostegus (Kropp and Manning 1987: fig. 10d, e). The shape of this tunnel is virtually identical to those found with O. hypostegus crabs in A. lamarcki at shallower depths (Panel A: Slangenbaai, Curaçao). Hence, we contend that this is strong evidence of O. hypostegus at mesophotic depth. In addition to the Atlantic species O. hypostegus, Opecarcinus has eight members associated with Agariciidae in the Indo-Pacific region, where specimens have been observed at shallow reefs between 1 and $24 \mathrm{~m}$ (Kropp 1989, Hoeksema and van der Meij 2013, van der Meij 2014b). In contrast, the closely related species Luciades agana Kropp and Manning, 1996 has been recorded from $34 \mathrm{~m}$ and 128-137 $\mathrm{m}$ in the agariciid Leptoseris papyracea (Dana, 1846), a delicate coral species known to occur in a wide depth range (Dinesen 1980, Komatsu and Takeda 2013).

So far, gall crabs and other coral-associated fauna (e.g., see Hoeksema et al. 2012) have been sampled mostly on shallow reefs due to technical limitations of scientific diving deeper than 30-35 m. Previous deep gall crabs records were all obtained by dredging. The availability of rebreathers, ROVs, and small submarines equipped for collecting allow further explorations of deep coral-associated fauna. The present finding is relevant in the light of the "deep reef refugia" hypothesis, which states that mesophotic reefs may act as a refuge in the face of global reef decline (Bongaerts et al. 2010), as it furthers our knowledge on the communities that presently thrive on these deep reefs.

\section{ACKNOWLEDGMENTS}

We are indebted to "Dutch" Schrier of Substation Curaçao for allowing us to get aboard the CuraSub. This publication is Ocean Heritage Foundation / Curaçao Sea Aquarium / Substation Curaçao (OHF/ CSA/SC) contribution number 14. This research was also supported by the CARMABI Research Station. Fieldwork by the first author was funded by KNAW (Schure-Beijerinck-Poppingfonds) and the TREUBmaatschappij (Society for the Advancement of Research in the Tropics). Fieldwork by the second author was funded by the JJ ter Pelkwijkfonds, AM Buitendijkfonds, and LB Holthuisfonds (all Naturalis). We thank two reviewers for their constructive comments.

\section{Literature Cited}

Bongaerts P, Ridgway T, Sampayo EM, Hoegh-Guldberg O. 2010. Assessing the 'deep reef refugia' hypothesis: focus on Caribbean reefs. Coral Reefs. 29:309-327. http://dx.doi.org/10.1007/s00338-009-0581-x

Bongaerts P, Frade PR, Ogier J, Hay KB, van Bleijswijk ), Englebert N, Vermeij M)A, Bak RIM, Visser PM, Hoegh-Guldberg O. 2013. Sharing the slope: depth partitioning of agariciid corals and associated Symbiodinium across shallow and mesophotic habitats (2-60 m) on a Caribbean reef. BMC Evol Biol. 13:205. http://dx.doi.org/10.1186/1471-2148-13-205

Dinesen ZB. 1980. A revision of the coral genus Leptoseris (Scleractinia: Fungiina: Agariciidae). Mem Queensi Mus. 20:181-235.

Hoeksema BW, van der Meij SET. 2013. Gall crab city: an aggregation of endosymbiotic crabs inhabiting a colossal colony of Pavona clavus. Coral Reefs. 32:59. http://dx.doi.org/10.1007/s00338-012-0954-4

Hoeksema BW, van der Meij SET, Fransen CHTM. 2012. The mushroom coral as a habitat. J Mar Biol Assoc UK. 92:647663. http://dx.doi.org/10.1017/S0025315411001445

Komatsu H, Takeda M. 2013. Second record of Luciades agana Kropp and Manning, 1996 (Crustacea, Decapoda, Cryptochiridae) from Tonga, South Pacific. Bull Natl Mus Nat Sci Ser A. 39:11-14.

Kropp RK. 1989. A revision of the pacific species of gall crabs, genus Opecarcinus (Crustacea: Cryptochiridae). Bull Mar Sci. 45:98-129.

Krop RK, Manning RB. 1987. The Atlantic gall crabs, family Cryptochiridae (Crustacea: Decapoda: Brachyura). Smithson Contrib Zool. 462:1-21. http://dx.doi.org/10.5479/si.00810282.462

van der Meij SET. 2014a. Host species, range extensions, and an observation of the mating system of Atlantic shallowwater gall crabs (Decapoda: Cryptochiridae). Bull Mar Sci. 90:1001-1010. http://dx.doi.org/10.5343/bms.2014.1017

van der Meij SET. 2014b. A new species of Opecarcinus Kropp \& Manning, 1987 (Crustacea: Brachyura: Cryptochiridae) associated with the stony corals Pavona clavus (Dana, 1846) and P. bipartita Nemenzo, 1980 (Scleractinia: Agariciidae). Zootaxa. 3869:44-52. http://dx.doi.org/10.11646/zootaxa.3869.1.4

Date Submitted: 10 October, 2014.

Date Accepted: 26 January, 2015.

Available Online: 12 February, 2015. 